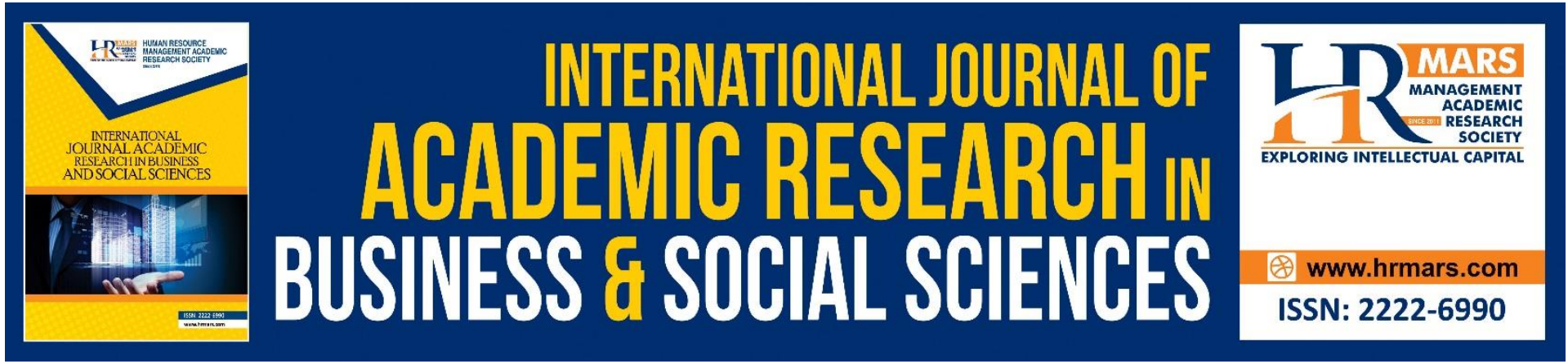

\title{
Politeness Strategies in the Criminal Trial
}

Norizah Ardi, Mazlina Mohamad Mangsor, Mazlifah Mansoor, Amirah Ahmad

To Link this Article: http://dx.doi.org/10.6007/IJARBSS/v11-i6/10324

DOI:10.6007/IJARBSS/v11-i6/10324

Received: 11 April 2021, Revised: 16 May 2021, Accepted: 28 May 2021

Published Online: 19 June 2021

In-Text Citation: (Ardi et al., 2021)

To Cite this Article: Ardi, N., Mangsor, M. M., Mansoor, M., \& Ahmad, A. (2021). Politeness Strategies in the Criminal Trial. International Journal of Academic Research in Business and Social Sciences, 11(6), 12391250.

\section{Copyright: @ 2021 The Author(s)}

Published by Human Resource Management Academic Research Society (www.hrmars.com)

This article is published under the Creative Commons Attribution (CC BY 4.0) license. Anyone may reproduce, distribute, translate and create derivative works of this article (for both commercial and non-commercial purposes), subject to full attribution to the original publication and authors. The full terms of this license may be seen at: http://creativecommons.org/licences/by/4.0/legalcode

Vol. 11, No. 6, 2021, Pg. 1239 - 1250

http://hrmars.com/index.php/pages/detail/IJARBSS

Full Terms \& Conditions of access and use can be found at http://hrmars.com/index.php/pages/detail/publication-ethics 


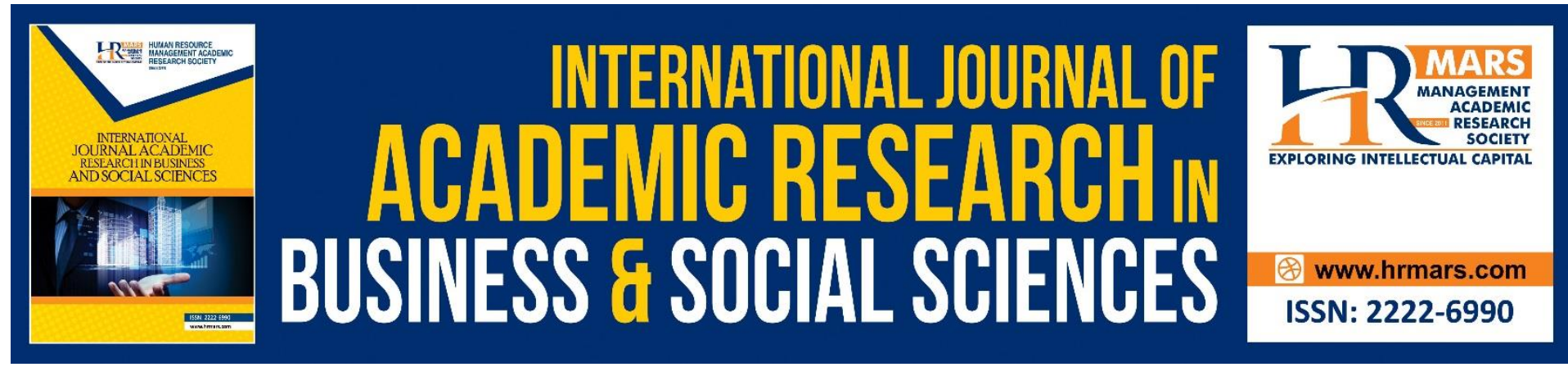

\title{
Politeness Strategies in the Criminal Trial
}

\author{
Norizah Ardi ${ }^{1}$, Mazlina Mohamad Mangsor², Mazlifah Mansoor ${ }^{3}$, \\ Amirah Ahmad ${ }^{4}$ \\ ${ }^{1,4}$ Akademi Pengajian Bahasa, ${ }^{2,3}$ Faculty of Law, Universiti Teknologi MARA, 40450 Shah \\ Alam Selangor \\ Email: norizah@uitm.edu.my
}

\begin{abstract}
Politeness is one of the aspects in pragmatic studies that is still relevant to this day. In court trials, whether involving criminal or civil case trials, the speakers is bound by the court ethics. The legal mechanism includes legislation to guide and promote fairness involving the Evidence Act 1950, Criminal Procedure Code and Advocate (Practice and Etiquette) Rules 1988. It is crucial to utilize positive politeness to ensure justice in criminal trial. The current development raises concern on politeness strategies from the highest hierarchy to the lowest hierarchy in a criminal court trial. This study adopted a qualitative methodology applying the case content analysis approach. Therefore, this paper aimed to study the politeness strategies during the cross-examination in court trials based on the excerpt from the summary of a selected case. This study found that the politeness strategies in criminal trials is crucial in upholding fairness in judicial decisions.
\end{abstract}

Keywords: Politeness Strategies, Courtroom, Pragmatics, Criminal Case

\section{Introduction}

Language plays an extremely important role in a courtroom trial whether it involves a civil case or a criminal case. Language usage in a courtroom is based on codes and ethics that demand decency and politeness during the trial.

Politeness has been interpreted as strategies to minimize conflict in social interaction (Lakoff, 1975). While Fraser and Nolan (1981:96) defined politeness is a communication contract use by the speakers and hearer as an effort to maintain congenial communication without triggering any conflict. In Malay language, politeness is not a strategies or communication contract, but it is a value to hold in an individual. Asmah (2000:88) stated that politeness is the use of everyday language that does not cause aggravation, resentment, and offense to the hearer.

A courtroom is a solemn place which requires parties to observe courtroom decorum by maintaining a respectful attitude at all times. The judges, prosecuting officers, counsels, witnesses and accused person must adhere to professional courtesy when communicating in court. The law regulates the mannerism in examination of witnesses. Sections 151 and 152 of the Evidence Act 1950 prohibit indecent or scandalous questions or inquiries in court. The court forbids offensive courtroom strategies which are intended to insult or annoy any parties. Counsels are also expected to observe the code of ethics in a trial. Rule 13 of the 
Advocate (Practice and Etiquette) Rules 1988 states that a counsel should exercise to exercise good judgment in examining witnesses in a trial. A counsel should refrain from asking an insulting or annoying question to witnesses. This is especially when the line of questioning is attacking the character of a witness which is not necessary to the facts in issue (Rule 14 of the Advocate (Practice and Etiquette) Rules, 1988).

As a noble place, how is politeness strategies being employed in courtroom discourse to represent the institutional? And what is the politeness strategies, if there is any, are used in courtroom trial by the participants? Secondly, what is the illocutionary functions conveyed by the participants during the cross-examination? Finally, what might be the findings of this study could be conclude between daily conversation and legal language?

Previous studies show that the study of politeness strategies have been widely been discussed in several types of texts such as novel, film, advertisement, political speech/campaign; and genres academic, humour and others. This theoretical framework has been widely used in analysing various types and genres of text particularly relating social interaction such as politeness in request strategies (Rue, Zhang \& Shin, 2007); politeness in compliment strategies (Golato, 2005); politeness in academic (Gunawan, 2014) and politeness in ICT communication (Mohammad, Davoudi, \& Ramezanzadeh, 2016; Herri, Debby \& Gunawan, 2019).

Even though, the research of politeness has been done more than 30 years since one of the pioneer studies was in late 1960s (Goffman, 1967) regarding the face-to-face behaviour in the risk of maintaining the face during the illocutionary functions or remarks in daily routine conversation), still this topic is relevant to be discuss especially in legal language. It is because, there were not many studies of politeness strategies in legal language especially focusing on court trial in Malaysia. One of the earliest studies of politeness strategies in courtroom language has been done by Cashion (1985) which focusing on politeness strategies used by the male and female judges during court trial from two civil case in Beverly Hills (California) Municipal Court. The transcribed data of 59 turns by the judge, 85 by the prosecuting attorney, 88 turns by the witness (the plaintiff), and 73 turns by the defence attorney was analysed based on the Brown and Levinson's theory of politeness (1978). Cashion (1985) found that the female judges use more super polite forms; but there was a male judge use the most politeness strategies. This study concluded that there was a small number of significance differences based on gender, but if based on the status as a judge, there is no difference in terms of the use of politeness strategies.

Liao (2019) also employed the same theory of politeness strategies (Brown \& Levinson, 1987) to analyse the courtroom language in civil and criminal trials in China. This study also adapted politeness model from Leech (1983) to analyse the illocutionary functions involved during the trials and Gu Yueguo (1998) of Politeness Principle for modern Chinese to study the courtroom trial in Chinese context. Liao (2019) concluded that politeness in courtroom discourse as a typical example of institutional discourse is fundamentally different from that in everyday conversation, and the findings turn out that various strategies and forms of politeness employed by the participants in the courtroom trial. The studies showed that, the judge used the politeness strategies in the whole process of trial especially during the court sentencing to the defendant as well as to the opposing lawyers.

Although, there were many scholars discussed about politeness strategies in Malaysia context such as in engagement ceremony (Noriati, 2013); radio talk show (Siti Nurbaya \& Azirah, 2011); motivation speech (Abd. Ganing, 2015); and television program (Rohaidah et. al, 2014), but the study of politeness strategies in courtroom trial specifically in criminal case 
are still under research compare with the scholars from abroad. Therefore, this study aims to analysing politeness strategies in courtroom specifically during the cross-examination of crime case. This study adapted the theory of politeness proposed by Brown and Levinson $(1978,1987)$ and illocutionary functions (Leech, 1983) to identify the language usage during the cross-examination.

\section{Politeness Strategies}

There are a few models of politeness proposed by prior scholars such as Cooperative Principle (Grice, 1975); Politeness Model (Lakoff, 1975); Politeness Principle (Leech, 1983); Conversational Contract (1990); and Politeness Theory (Brown \& Levinson, 1978, 1987). Brown and Levinson's theory of politeness $(1978,1987)$ have made significant contributions to the development of pragmatics studies and have been used extensively as a theoretical framework in politeness research. In this theory, Brown and Levinson state that every social interaction between speakers $(\mathrm{S})$ and addressees/hearer $(\mathrm{H})$ are related to 'face'. Face is an individual's self-esteem. Goffman (1967:5) states the term face may be defined as the positive value a person effectively claims for himself by the line others assume, he has taken during a particular contract. Brown and Levinson (1978) claimed that everyone has positive face which signifies their actions and thoughts are recognized by others as something good, pleasant, worthwhile etc.; and negative face which implies that they will be rewarded for allowing them to be free to act without interference. In social interaction, $S$ will avoid making face threatening acts (FTAs) that Brown and Levinson called as strategy 5: Don't do the FTA (Refer to Figure 1).

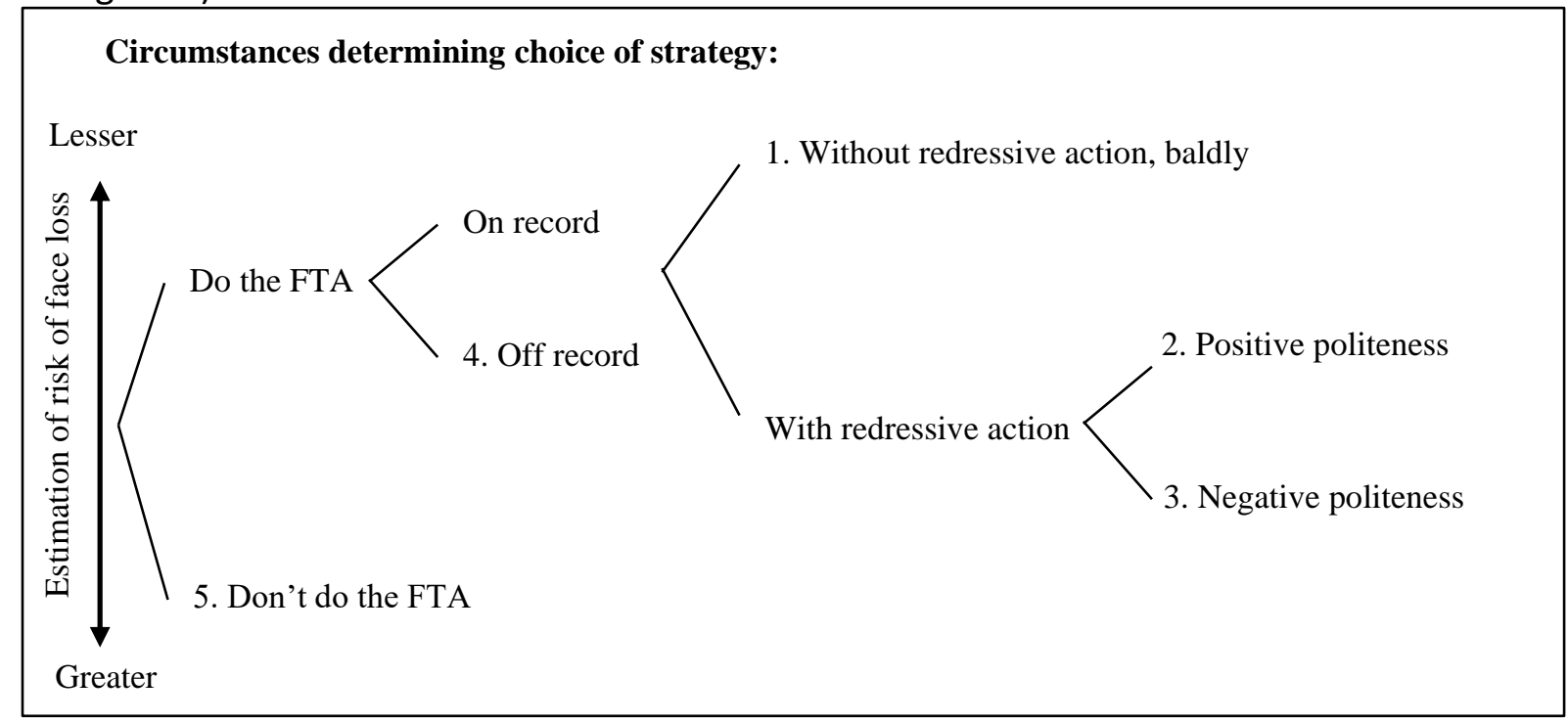

Figure 1: Politeness strategies (Brown \& Levinson, 1987)

Basically, there are four strategies of politeness (Brown \& Levinson, 1987) when a speaker performs the FTA which are:

Bald on record (baldly) without redressive action considered impolite because the speaker does not attempt to minimize the FTA to the hearer.

(a) Positive politeness is a strategy to prioritise the hearer's positive face and to show solidarity. The speaker normally has the power of higher status would use this strategy when converse with the hearer who has the least status. 
(b) Negative politeness is a strategy to maintain the hearer's negative face and to show a respect in social interaction. Negative politeness usually used by the speaker who have the least status from the addressee.

(c) Bald off record is a strategy to maintain the respect for the hearer's negative face by using metaphors or irony; implicit statement such as proverbs. The speaker conveys the meaning vaguely to avoid the speaker being accountable by any interpretation.

\section{Illocutionary Function}

Different kinds and degrees of politeness are called for in different situations. Leech (1983:104) states that illocutionary functions may be classified into four types: (a) competitive; (b) convivial; (c) collaborative; and (d) conflictive. The first two types are the ones which chiefly involve politeness.

(a) Competitive: The politeness is of a negative character, and its purpose is to reduce the discord implicit in the competition between what $\mathrm{S}$ wants to achieve, and what is good manners. The goals are those which are essentially discourteous such as ordering, asking, demanding, begging etc.

(b) Convivial: The politeness is of a more positive form of seeking opportunities for comity and contrary of competitive. The goals are those essentially courteous such as offering, inviting, greeting, thanking, congratulating etc.

(c) Collaborative: This is which politeness is largely irrelevant because mostly this will involve written discourse. The illocutionary goal is indifferent to the social goal such as asserting, reporting, announcing, instructing etc.

(d) Conflictive: This is by nature is impolite because it is designed to cause offence. The illocutionary goal conflicts with the social goal such as threatening, accusing, cursing, reprimanding etc.

This study will refer to the Politeness Theory proposed by Brown and Levinson $(1978,1987)$ in terms of face and face wants, while when discussing about the illocutionary functions, the framework stated by Leech (1987) will be referred.

\section{Data and Methodology}

This study employed a qualitative method through content analysis based on the context of the court trial conveyed. The contextual in this study refers to the message context which means the indirectness and implicitness of the message itself. Message context is cues that convey implied and inferred meaning accompanying the utterance. Triandis (1972) mentioned indirect and implicit messages contain information hidden in the socio-cultural system. Or, in internal context-information contained within the individual (Hall, 1976).

Politeness is the study of how language is used to strategize the illocutionary functions during the conversation or social interaction. Hence, the type of data used in this study is utilized from authentic written data which is an excerpt of transcription of court trials from summary of case. The data was taken from excerpts in a summary of case Ahmad Norizan Mohamad v. PP (taken from CL Law). Excerpts from the summary was analysed based on the context in a courtroom trial of criminal case under sections $39 \mathrm{~B}(1)(\mathrm{a})$ of the Dangerous Drugs Act 1952 for trafficking in cannabis and section 39A(2) and section 6 for possession of cannabis. This is an appeal from the accused (OKT) under section165 of Evidence Act 1950. Descriptive analysis of the context in this study should have the knowledge of speakers and 
addressees' status that involved in the conversation. Figure 2 show the background and status of speakers and addressees involved in this trial.

\begin{tabular}{lc|c|}
\hline \multicolumn{2}{|c|}{ Learned Judge } & highest hierarchy \\
\cline { 1 - 2 } Prosecution & Lawyer & lowest hierarchy \\
\hline Witnesses & The accused (OKT) & low
\end{tabular}

Figure 2: Status of speakers and addressees in a court trial

In order to discuss about the politeness strategies, there are three sociological factors need to be considered to explain the choice of politeness strategies and the level of the face threatening action which are: distance between speaker and listener; the power difference between the speaker and listener; and ranking of the seriousness of the face threat. Although neutral politeness should be expected in court trial, in fact politeness varies with the participants' roles and status. Customarily, the judge possesses greater respect and the defendant, or the accused is the least. The abbreviations employed in the following excerpts are ' $\mathrm{S}$ ' for a prosecutor/judge/lawyer, ' $\mathrm{J}$ ' for an accused, 'Mah' for a judge and 'TPR' for a deputy public prosecutor. The utterances conveyed by the speakers and addresses were analysed based on the politeness strategies (Brown \& Levinson, 1978, 1987) and illocutionary functions (Leech, 1983).

\section{Results and Discussion}

As mentioned earlier, courtroom is a solemn place which always requires parties to observe courtroom decorum by maintaining a respectful attitude. The utterances conveyed by the speakers were analysed based on the illocutionary functions (Leech, 1983) and politeness strategies (Levinson, 1978, 1987). The data that been discuss in this study was taken from the court proceedings of the summary case of Ahmad Norizan v. PP which is a criminal case under sections 39B(1)(a) of the Dangerous Drugs Act 1952 for trafficking in cannabis and section $39 \mathrm{~A}(2)$ and section 6 for possession of cannabis.

\section{Bald on Record (Baldly)}

The learned judge baldly asked the accused during the cross-examination and drive him tight to the corner.

\section{Conflictive - Criticizing}

The Excerpt 1 shows the used of a conflictive illocutionary function which is criticizing. As mentioned earlier, conflictive function by nature is impolite because it is designed to cause an offense towards the hearer especially when the speakers intentionally criticized the hearer. Liao (2019) stated that in a criminal trial, when the accused does not behave as well as expected, the prosecutor would criticize him or her as in the following where the accused was criticized for assuming a poor attitude. But in Excerpt 1, it shows that the learned judge $(\mathrm{S})$ is the one who criticized the accused (J); and cynically criticized the answer given during the cross examination.

\section{Excerpt 1}

$S \quad$ : Apa sebenarnya hubungan kamu dengan Normira ini?

$J \quad$ : Sebagai adik angkat dengan abang angkat sahaja, Yang Arif. 


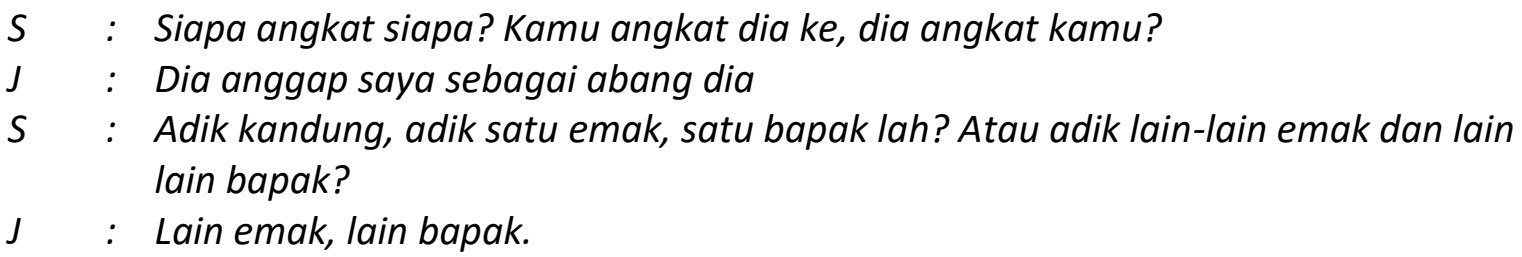

The learned judge also did the same thing when baldly interrupted the crossexamination between the prosecutor and the accused in the following excerpt. The trial judge has adopted a condemnatory approach by asking about the accused's relationship with the co-accused. In a criminal trial, a judge must refrain from making adverse comments or observations before the conclusion of the evidence. (Roseli bin Amat \& Ors v Public Prosecutor (1989) 1 LNS 103). The act of the trial judge in criticising the accused also means that he has prejudged the credibility of the accused before the rest of the evidence in the case (Panjavarnan against PP (1966) 1 LNS 130). As a judge, he should maintain neutrality in the whole process of trial, and not be prejudiced towards the accused.

\section{Competitive - Ordering}

The Excerpt 2 shows the used of competitive illocutionary function which is ordering. The competitive illocutionary function is politeness as a negative character, and its purpose is to reduce the discord implicit in the competition between what $S$ wants to achieve, and what is good manners. As a learned judge (Mah), he should not interrupt during the crossexamination between the $S$ (in the Excerpt 2, the $S$ refer to the deputy public prosecutor) and the accused (J). But in this context, the Judge is not only interrupting the cross-examination but also bluntly ordered the prosecutor to ask the accused directly which implicitly displays that as if the prosecutor did not use the proper questions during the cross-examination.

\section{Excerpt 2}

$S \quad$ : Saya katakan memang kamu dengan Normira yang mendiami rumah tu sebab gambar kamu ada di ruang tamu turut dijumpai di dalam bilik hadapan jugak, pakaian kamu dan Normira turut dijumpai di dalam bilik itu jugak?

J : Tidak setuju.

Mah : Can you put straight to the witness. He try to say bermakna SD1 ada hubungan sulit dengan Normira? (Interruption)

$T P R: Y a$.

Mah : Dan mereka tidur di sana bersama-sama. Tidur di dalam bilik tu, dekat katil tu, gambar tu ada di kepala katil. Gambar dia orang berdua gambar berpelukan ada dalam rumah tu. Itu yang kita nak katakan? (Interruption)

TPR : Ya, Yang Arif.

Mah : Cakaplah straight supaya saksi faham supaya dia boleh jawab dan dia boleh nafikan atau pun dia mengaku kan. Barulah adil kepada dia.

TPR : Baik, Yang Arif.

The role of the prosecuting officer in the adversarial system is to prove the criminal case through the examination of witnesses. While the role of the court is to decide as to the admissibility of evidence and to supervise the parties to maintain order in the courtroom (section 136 Evidence Act). The Judge must refrain himself from asking questions to supplement the case for the prosecution (section 256 (7) of the criminal procedure code). 
Excessive interruptions by the Judge in the Excerpt 2 shows that the Judge castigating him as for the way he conducted the examination. The prosecuting officer was not allowed to examine witnesses by using his choice of words.

Also, the fact that the Judge asked the prosecuting officer to ask openly (cakaplah straight) about the accused's sexual relationships are regarded as improper conduct that went beyond the scope of the examination. This is in breach of section 256(5) of the Criminal Procedure Code which prohibits the Judge to induce an accused person to make a criminatory statement of himself. The Excerpt 2 also shows the Judge was threatening the prosecutor's face by ordering baldly, as well as induce the accused to answer the question as his request (Itu yang kita nak katakan?).

\section{Positive Strategies}

Positive strategies in this context are seldomly used by the judiciary in conducting the trial. In this positive strategy, the speaker normally has the power of higher status would use this strategy when converse with the hearer who has the least status. In Excerpt 3 crossexamination, the court employed the competitive-fairness strategies whereby there was a positive-politeness utterance when a judge which has the higher status concerned for hearer's wants (least status) through the following utterance.

\section{Competitive - Fairness}

The Excerpt 3 shows the used of competitive illocutionary function which is fairness. In this context, the competitive illocutionary function shows by the learned judge as being fairness and by prioritise the hearer's positive face. The learned judge (Mah) tried to be fair during the cross-examination towards the accused by ordering the prosecutor (TPR) to revised his questions.

\section{Excerpt 3}

Mah : Cakaplah straight supaya saksi faham supaya dia boleh jawab dan dia boleh nafikan atau pun dia mengaku kan. Barulah adil kepada dia.

TPR : Baik, Yang Arif.

Being the highest in the hierarchy, the Judge in this case uttered the phrase 'barulah adil kepada dia' to the deputy public prosecutor to show the judicial consideration in emphasising the need to practice fairness and addressing positive face towards the accused. The utterance conveys by the Judge show fairness towards the accused in trial during the cross-examination. The context show that the Judge demonstrate positive value with regard of the accused position in the trial.

\section{Negative Strategies}

Negative strategies in this context of the study became a common strategy by the deputy public prosecutor in establishing a case against the accused. However, there is also the utterance convey by the learned judge and the accused that implied negative strategy. The Excerpt 4 show both parties, the learned judge and the accused had adopted the negative strategy to address a third party using a 'Mr.' as uttered by both of them and referred to 'Mr. Wong'. In addition, the accused was also in a similar vibe by showing his respects towards the learned judge by calling him 'Yang Arif'. 


\section{Competitive - Asking}

The Excerpt 4 shows the used of competitive illocutionary function which is asking. In this cross-examination, the learned judge (S) questioned the accused $(\mathrm{J}$ ) about the possession of the house that has been used for the labour works.

\section{Excerpt 4}

$S \quad:$ Rumah siapa tu?

J : Rumah Mr. Wong.

$S \quad$ : Kenapa pulak tinggal dekat sana kalau rumah Mr. Wong?

$\mathrm{J} \quad$ : Saya ada buat kerja maintenance dekat kondo ini Yang Arif.

During the cross-examination, the learned judge $(\mathrm{S})$ also used the same term of address to refer to the third party in asking to the accused. In this negative strategy, when a person called someone with certain term of address, it is to show that the person implied to minimise the FTA. Although the accused show his respects towards the learned judge based on the above excerpt, but there was a situation he is being impolite. This is because there is also a reply from the accused who should implies negative politeness, but he had posed a face threat to the judges by using affirmation of "kan" and "tadi" as in the following excerpt.

\section{Conflictive - Asseveration}

The Excerpt 5 shows the used of conflictive illocutionary function which is asseveration. As a person that has least hierarchy in the conversation, the accused should demonstrate politeness strategies towards the highest hierarchy in the context of conversation during the cross-examination.

\section{Excerpt 5}

$S \quad$ : Kamu kata nak masuk palang perlukan kad pass kan, jadi macam mana dia boleh masuk?

J : Pasal Awi dah beberapa kali pergi, jadi jaga di situ memang dah tahu budakbudak pekerja saya.

$S \quad$ : Jadi maksudnya kamu memang tinggal di situ sebab itu pengawal pun tahu siapa kawan-kawan kamu yang akan masuk?

J : : Kan saya dah cakap tadi saya tinggal di situ sebelum saya kahwin.

Being in the least hierarchy in the context of trial, the accused should imply negative strategy by answering the questions politely and avoid using words like 'kan' and 'tadi' to show his asseveration. As an alternative, he could response as "saya sudah bagitau yang saya tinggal di situ sebelum saya kahwin" to minimise the FTA.

\section{Bald off Record}

Supposedly, in this context, the usage of implicit language is to illustrate politeness bald off record. However, the judge utilised impolitely the strategy and resulted in face-threatening the accused. The following conflictive goals with accusation and mocking nature reflected the above-mentioned politeness strategies. 


\section{Conflictive - Accusation}

The Excerpt 6 shows the used of conflictive illocutionary function which is accusation. In this context, the conflictive illocutionary function shows by the learned judge (Mah) as accusation towards the accused $(J)$ during the cross-examination. The unfair accusation made by the Judge pressured the accused to explain unnecessary and irrelevant matters to the Judge who is also the person deciding over the case.

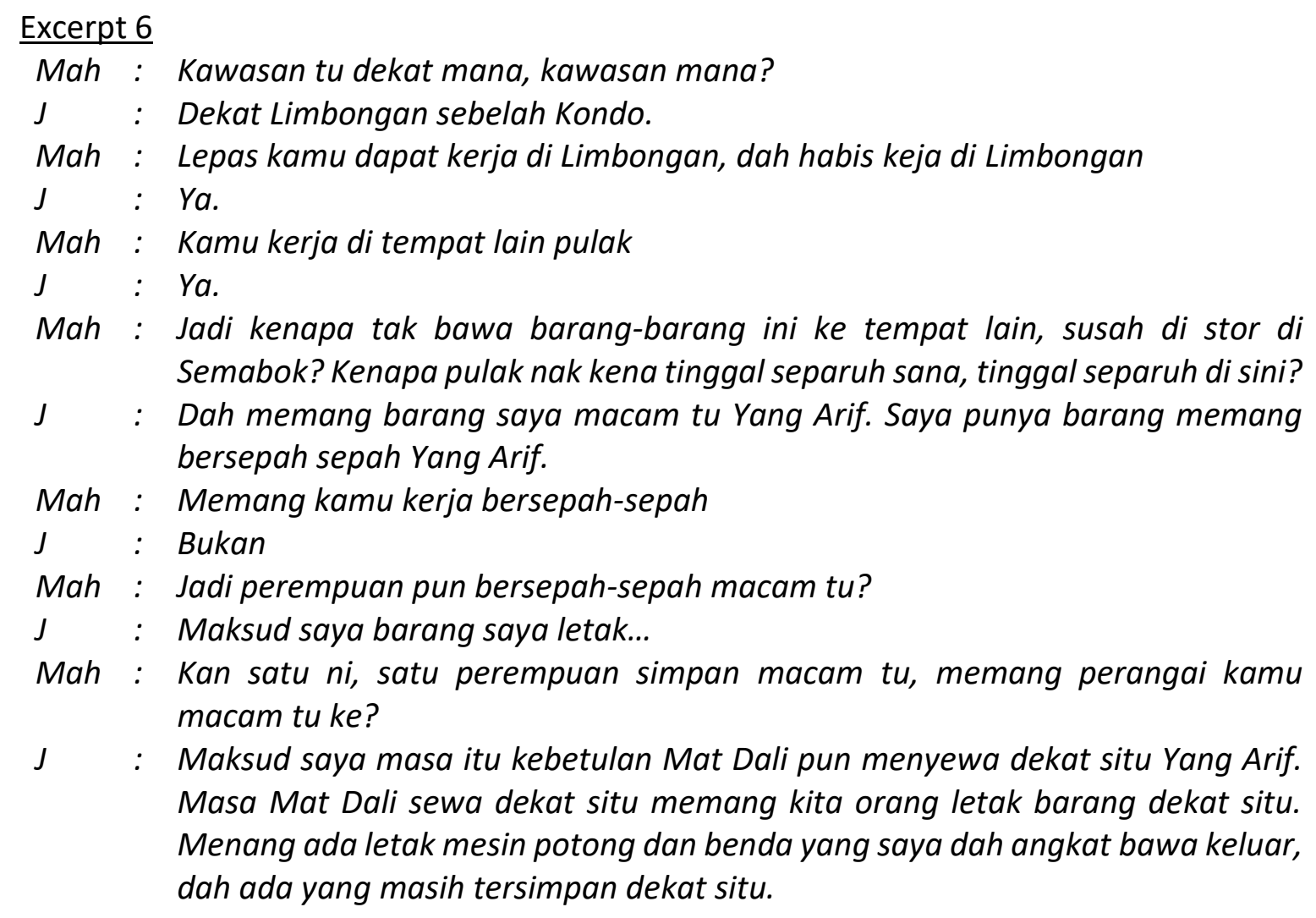

The power of the judge to ask questions from the accused only to explain facts that may stand against him unexplained (Section 256 (6) Criminal Procedure Code). Also, section 165 of the Evidence Act provides that, asking questions by a judge is allowed when the judge considers it necessary to the case. However, the excerpt above shows that the judge has used a hostile approach by showing he was annoyed with the answer given by the accused. The Judge even went further to criticise the accused's relationship with a woman as stated in "perempuan pun bersepah-sepah" meaning that the accused have scandal with many women.

\section{Conflictive - Mocking}

The Excerpt 7 shows the used of conflictive illocutionary function which is mocking. The conflictive illocutionary function shows by the learned judge (Mah) as mocking towards the accused $(J)$ in this context. The learned judge scorned the accused's statement by saying the accused is not the person who can read the thoughts of the police officer in charge. 


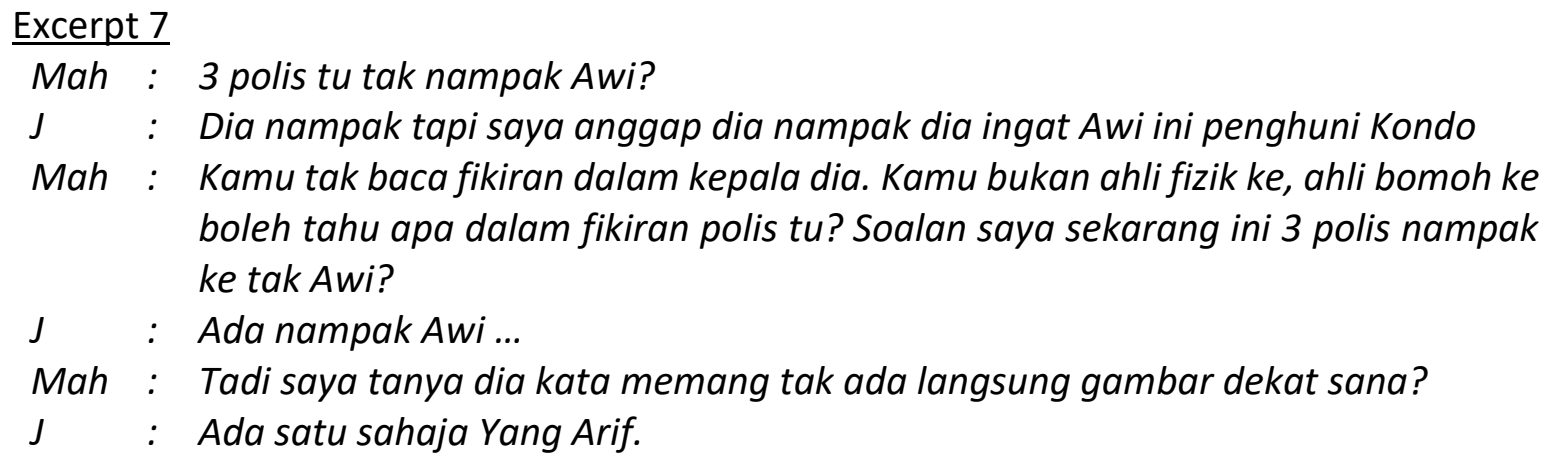

As shown in the above excerpt, the judge has ridiculed the answer given by the accused person by suggesting that the accused cannot discern the thoughts of others without any expert knowledge. The evidence given by the accused was controlled very closely by the Judge which did not give a room for the accused to testify using his own words. Criticism by the learned judge on the evidence given by the accused may lead to prejudice and bias against the accused person. In the case of Awaluddin Suratman \& Ors v Public Prosecutor (1991) 2 $\mathrm{CL} 310$, it was decided that the trial judge has to act impartially between the prosecution and undefended accused person.

\section{Conclusion}

Politeness strategies in criminal trials is crucial in upholding fairness in judicial decisions in Malaysia. This study found that the illocutionary functions are performed in two main types of competitive and conflictive. Competitive goals of discourteous in nature were reflected in the bald on record (Baldly) by ordering in which the learned judge interrupted the cross examination between a prosecutor and an accused. This study found that the bald on record and bald off record strategies conveyed by the learned judge in the reviewed case was surpass the deputy public prosecutor's role. Hence, it is an opportunity to the accused to make an appeal of his sentence. However, a positive strategy of competitive highlighted a goal of fairness between a judge and a deputy public prosecutor. Negative strategies involving competitive-asking goals was found between the deputy public prosecutor and the accused.

The conflictive goals dominated the politeness strategies in the reviewed case. They are bald on record related to conflictive nature with criticizing goals between the learned judge and the accused; conflictive with asseveration goals between the deputy public prosecutor and the accused; bald off record of conflictive goals with accusation and mocking between the highest hierarchy, the judge and the least hierarchy, the accused. The impolite nature of the conflictive goals may result in causing offences in which able to compromise the fairness of the criminal trial.

\section{References}

Laengkang, A. G. (2015). Analisis Kesantunan Bahasa dalam Ceramah Motivasi Dr. Mohd. Fadzilah Kamsah. Serdang: Penerbit Adam Muslim.

Omar, A. H. (2000). Wacana Perbincangan, Perbahasan dan Perundingan. Kuala Lumpur: Dewan Bahasa dan Pustaka.

Brown, P. B., \& Levinson, S. C. (1978). Universals in language usage: politeness phenomena. In E. Goody (Ed.) Questions and Politeness: Strategies in Social Interaction. Cambridge: Cambridge University Press. 
Brown, P. B., \& Levinson, S. C. (1987). Politeness: Some universals in language usage. Cambridge: Cambridge University Press.

Cashion, J. L. (1985). Politeness in courtroom language. Conference of the Western Speech Communication Association, 16-19 February.

Fraser, B., \& Nolan, W. (1981). The association deference with linguistic form. International Journal of the Sociology Language, 27, 93-109.

Fraser, B. (1990). Perspectives on politeness. Journal of Pragmatics, 14, 219-236.

Golato, A. (2005). Compliments and compliment responses: Grammatical structure and sequential organization. Amsterdam: John Benjamins Publishing Company.

Goffman, E. (1967). Interaction Ritual: Essays on Face-to-Face Behavior. New York: Doubleday.

Grice, H. P. (1975). Logic and Conversation. In Cole et al. (Eds.). Syntax and Semantics 3: Speech Act (pp. 41-58). Elsevier.

Gunawan, F. (2014). Representasi kesantunan Brown dan Levinson dalam wacana akademik. KANDAI, 10 (1), 16-27.

Hall, E. T. (1976), Beyond Culture. New York: Doubleday.

Lakoff, R. T. (1975). Language and Women's Place. New York: Harper and Row.Legal Profession (Practice and Etiquette) Rules 1978.

Liao, M. (2019). Politeness in the courtroom discourse. Forensic Research Criminal International Journal, 7(2): 45-61. DOI: 10.15406/frcij.2019.07.00264.

Abd. Rashid, N. (2013). Kesantunan orang Melayu dalam Majlis Pertunangan. Tanjong Malim: Penerbit Universiti Pendidikan Sultan Idris.

Rue, Y. J., Zhang, G., \& Shin, K. (2007). Request strategies in Korean. 5th Korean Studies Association of Australasia (KSAA) Biennial Conference, 12-13 July.

Siti Hajar C. M., Munir, S., Razif, M., \& Kaur, S. (2012). Kesedaran dan Amalan Kesopanan dalam Kalangan Remaja Malaysia: Menilai Sumbangan Teori Kesopanan Brown Levinson. Akademika. 82(2), 81-85.

Siti Nurbaya, M. N., \& Azirah, H. (2011). Disagreement Strategies of Malaysian Speakers of English Discourse. 12th Asia Pacific Research Universities (APRU) Doctoral Students Conference Proceedings. 28-20 October.

Triandis, H. C. (1972). The analysis of subjective culture. New York: Wiley. 